\title{
En nasjon uten midjefett?
}

\author{
Nå skal vi løpe i motbakke \\ til vannet går.
}

«Kom dere ut og opp i bakkene!» Det var oppfordringen landets gravide kvinner nylig fikk i Dagens Næringsliv. «Graviditet og fødsel brukes som unnskyldning for å ikke trene,» hevdet medisinske eksperter. I artikkelen kunne vi videre lese om Anne Margrethe, som løp orientering i åttende måned, og Laila, som gikk på rulleski fire dager etter fødselen.

Nettstedet Barn i magen slo i sommer opp et bilde av en usedvanlig flat og stram mage under tittelen Dette er Linn (26) fire måneder etter fødselen. Linn trente opptil seks dager i uken gjennom hele graviditeten, kunne vi lese her. Hensikten med slike historier er antagelig å inspirere sofapotetene. Men jeg er redd de fører til at allerede «flinke» kvinner blir enda strengere mot seg selv.

Tidligere ble gravide fortalt at de skulle hvile flere timer om dagen. Nå er tonen altså strengere. I dag har helseautoritetene bare ett svar på de fleste av livets utfordringer: Tren! Er du syk, skal du trene deg frisk. Er du deppa, skal du trene deg glad. Er du gravid, skal du trene til vannet går. Og hvis du ikke orker, må du skjerpe deg! Slutt med disse unnskyldningene dine!

Hvor ble det av de mer moderate stemmene i debatten? lurer jeg på. Er det virkelig ingen der ute som kan finne på å si: «Nei, legg deg på sofaen og slapp av litt, du, jenta mi. Jeg kan se at du er sliten.» Eller: «Det er faktisk ikke noen krise at du veier et par kilo for mye.»

Kanskje finnes det fremdeles noen i Helse-Norge som kunne tenke seg å nyansere budskapet, men som ikke våger? For det er lett å få hodet hugget av. Vi husker fremdeles at den nyvalgte LOlederen Gerd Kristiansen fortalte til VG at hun syntes treningshysteriet hadde gått for langt og at hun i stedet samler krefter på kino, konsert eller med en god bok i sofaen. Hun ble angrepet fra en rekke hold og stemplet som uansvarlig og gammeldags.

Det samme skjedde da et knippe samfunnstopper uttalte seg i artikkelen Treningsløst i Dagens Næringsliv for et par år siden. De var lei av å lese intervjuer med selvtilfredse sjefer i sykkelshorts hver gang de åpnet avisen. Det finnes andre verdier i livet enn pulsverdier, hevdet de. Men kritikken kom lynraskt: Dette var kunnskapsløse tullinger som ikke visste hva de snakket om, mente en idrettsprofessor.

Da jeg skrev boken Rosa streker, røde tall, som handlet om graviditet og fødsel $i$ et stadig mer markedsstyrt helsevesen, snakket jeg med flere kvinner om den økende oppmerksomheten omkring vekt i svangerskapsomsorgen. At det er viktig å fors øke å holde seg sunn og frisk, forstår selvsagt alle, men noen av dem jeg var i kontakt med, fortalte at legens og jordmorens snakk om vekt nærmest ødela svangerskapet. Det ble ikke plass til andre gleder eller bekymringene rundt det som skulle skje - alt handlet om de ekstra kiloene.

Én overvektig kvinne forteller følgende på Barn i magen: «l dag var jeg hos legen, første gang i dette svangerskapet, og ble møtt av en lege som ba meg slanke meg umiddelbart og under svangerskapet. (...) Hun mente tykke damer ikke burde bli gravide. Hun spurte rett ut to ganger om hun ikke skulle henvise meg til fedmeoperasjon - noe jeg takket nei til, begge gangene. Da jeg sa at jeg var mye kvalm og kastet opp en del, var kommentaren: «Da blir det nok lettere å holde vekten.»»

Presset på å holde formen gjennom graviditeten har utvilsomt økt, også for mer normalvektige kvinner. Vi er i ferd med å utvikle en slags nulltoleranse for overvekt. Og hvis noen fors $\varnothing$ ker å vise fram virkeligheten - ved for eksempel å trykke et bilde av en fyldig modell i et moteblad eller bruke en gjennomsnittlig kvinne à la Lena Dunham i TV-serien Girls på bladets forside, roper mobben hissig: «Vet du ikke at midjefett er helsefarlig!»

Stadig flere virker overbevist om at det er et ubetinget gode for folkehelsen at samfunnet holder jevnt høyt søkelys på kropp og vekt. Landets mange helseeksperter og treningsguruer har antagelig en reell tro på at dersom du pøser ut budskapet ditt høyt nok og lenge nok, vil du til slutt nå målet: En nasjon uten midjefett.

Men innerst inne vet vi at uansett hvor mye myndighetene ønsker å presse oss alle inn den samme fysiske malen, så vil mange stå utenfor. Unge mennesker vokser opp og klarer ikke å identifisere seg med dagens kjernesunne, langrennsidealiserende Kari Jaquesson-offentlighet. Disse ungdommene trenger også forbilder. De trenger å få vite at det også er andre egenskaper og talenter som kan føre til et godt liv. De må få vite at de ikke balanserer på dødens rand, selv om de mangler sixpack og superkondis. På den måten kan vi også bedre den psykiske folkehelsen.

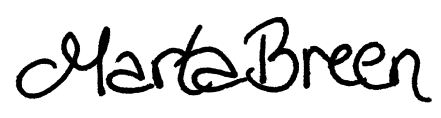

